\title{
Effect of Sales Growth, ROE, ROA and FAR Towards DER in Real Estate and Property Companies in Indonesia Stock Exchange
}

\author{
Halkadri Fitra', Lara Al Ashry ${ }^{2}$ \\ ${ }^{1}$ Universitas Negeri Padang, Padang, Indonesia $\bowtie$ halkadri@fe.unp.ac.id \\ 2 Universitas Negeri Padang, Padang, Indonesia
}

\begin{abstract}
This study aims to analyze the influence of (1) sales growth (2) Return On Equity (ROA) (3) Return On Assets (ROE) and (4) Fixed Asset Ratio (FAR) to Debt to Equity Ratio (DER) in real companies estate and property listed on the Indonesia Stock Exchange. This research is a causative study with a population of all real estate and property companies listed on the Indonesia Stock Exchange (IDX) in 2013-2017 and samples determined by purposive sampling technique based on the criteria of (1) real estate and property companies listed on the IDX, (2) companies that publish financial statements during the year of observation and (3) companies that have net income during the year of observation to obtain 65 companies. The type of data used is secondary data and the analytical method used is multiple regression analysis. The results of this study indicate (1) sales growth has a negative and not significant effect on DER (2) ROE has a positive and significant effect on DER (3) ROA has a negative and significant effect on DER, and (4) FAR has a positive and significant effect on DER.
\end{abstract}

Keywords: DER, sales growth, DER, ROA, FAR

\section{Introduction}

The Indonesia Stock Exchange (IDX) as the Self Regulatory Organization of the capital market in Indonesia is obliged to maintain trade momentum and strive to build trust in Indonesian capital market players. This can be seen from the performance of the Composite Stock Price Index (IHSG) and the stock trading volume that occurs on the trading floor at any time moving and changing which is influenced by various factors both positive and negative. The following is a description of the movement of the composite stock price index and trading volume for the period March 2018 to March 2019

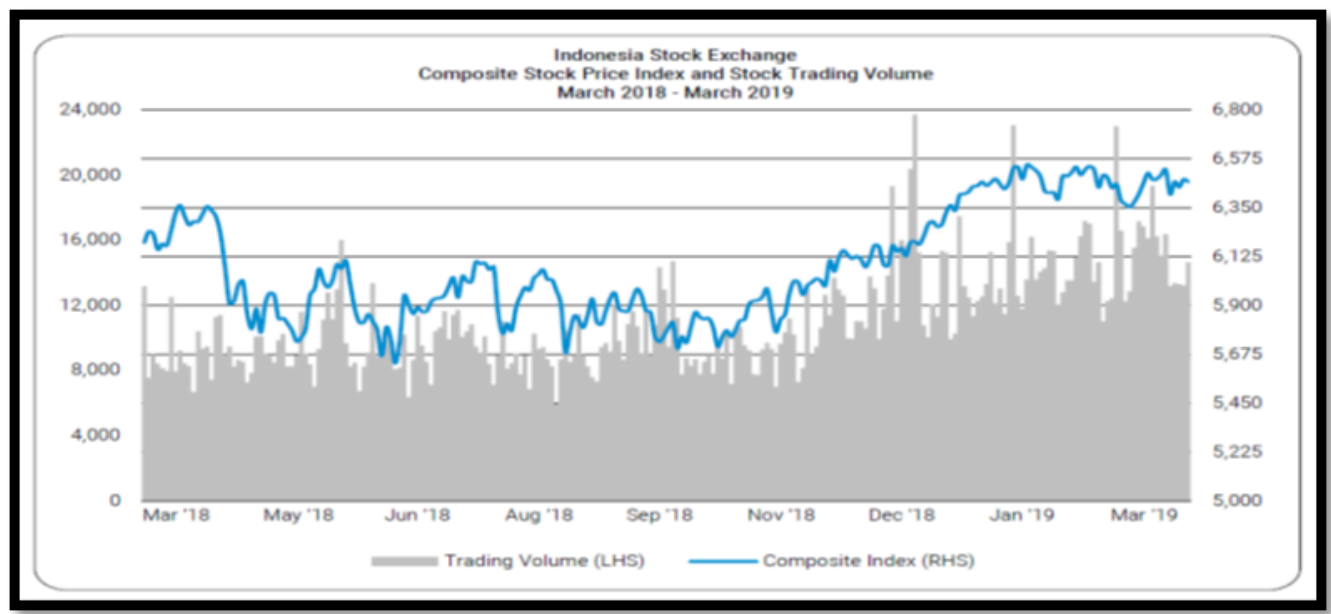

Figure 1. Composite Stock Price Index and Stock Trading Volume March 2018 to March 2019

Based on Figure 1, it can be noted that the IHSG in the March 2019 period experienced an increase compared to the period of March 2018 and during that period experienced an up and down trend, as well as the volume of stock trading, the period of March 2019 was higher compared to the March 2018 period. The real estate and property sector, which is one part of the sector in the Indonesia Stock 
Exchange, is inseparable from intense competition with other sectors to improve the superiority of the products produced, so as to increase the competitiveness of companies. The number of real estate and property companies listed on the Indonesia Stock Exchange has increased from 40 companies in 2010 to 49 companies in 2016 (www.sahamok.com). Companies need funding to run and develop businesses that are obtained from internal companies in the form of retained earnings and accumulated depreciation as well as external companies in the form of creditor funds and own capital (Riyanto, 2011). Corporate funding decisions are one of the important decisions faced by company managers in the continuation of the company's operations, hence the company requires an appropriate funding policy

Determination of appropriate funding decisions need to pay attention to several things, namely: (1) decisions regarding the determination of the source of funds needed to finance investment, (2) determination of the best balance of expenditure or often called the optimum capital structure (Martono and Harjitno, 2010). The optimal capital structure is where the condition of the company is able to use debt and equity ideally by balancing the benefits and costs of its capital structure. The more efficient the company costs can minimize the company's capital costs so that the company reaches the optimal capital structure. Capital structure is the balance of permanent short-term debt, long-term debt, preferred stock and ordinary shares (Sartono, 2008).

Capital structure is an important problem for every company and has an impact on the company's financial position. Errors in determining the capital structure will affect the sustainability of the company, especially if the company is too large in using debt, the burden that must be borne by the company is also greater. This can increase a company's financial risk if it cannot pay the interest expense or installments of its debt. Brigham and Houston (2011) state that if a company wants to grow requires capital, and capital in the form of debt and equity. Capital structure can be measured from the ratio of the ratio of total debt to own capital which is commonly called the debt to equity ratio (Husnan and Pudjiastuti, 2012). This is consistent with the opinion of Brigham and Houston (2011) which states that the Debt to Equity Ratio shows the composition of debt to total equity. The use of Debt to Equity Ratio is intended to facilitate measurement because the capital structure cannot be measured directly (Sartono and Sriharto, 1999). Given the Debt to Equity Ratio in the calculation is debt divided by own capital, then if the company's debt is higher than capital itself means the ratio of Debt to Equity Ratio is more than one or the use of debt is greater in financing company activities than own capital (Brigham and Houston, 2011).

Determination of the composition of capital structure is influenced by asset structure, sales stability, growth rate, profitability, operating leverage, taxes, controls, management attitudes, lender attitudes and rating agents, market conditions, internal company conditions, and financial flexibility (Brigham and Houston, 2011). The existence of factors that influence the company's capital structure is important as a basis for consideration in determining the composition of the company's capital structure. In this study, the researcher limits some of the factors that will be examined which are thought to influence the capital structure, namely sales growth, profitability and asset structure.

Sales growth is a factor that influences capital structure. The sales growth rate shows the rate of change in sales from year to year. The higher the growth rate, a company will rely more on external capital. A company whose sales are relatively stable will be safe in taking more debt and bear a higher fixed burden than companies whose sales are not stable (Brigham and Houston, 2011). In general, companies will need a lot of additional capital to expand their scale and market share. The higher the level of sales growth of the company, the greater the loan capital. Sales growth is measured by comparing the difference between sales in the current year and the previous year with the previous year's sales (Kesuma, 2009).

According to Weston and Brigham (2005), companies with rapid sales growth tend to use debt more than companies that grow slowly. In addition, sales growth will affect creditors in providing loans, where companies that experience good sales growth are considered to have good prospects in their development and this reduces risk (Sofiati, 2001). 
Companies that have a high level of sales growth need additional funds to support sales growth so that the use of funds will increase. According to the pecking order theory, companies prefer funding using sources originating from internal companies. Based on the pecking order theory, if the company has sales growth, then of course the company will have an internal source of funds from retained earnings which is the result of the company's sales growth. If the company tends to use retained earnings as a source of corporate funding, this will result in reduced debt usage in companies experiencing sales growth. Then it can be concluded that sales growth can affect the company's debt to equity ratio.

\section{H1: sales growth affects the Debt to Equity Ratio}

Profitability is also a factor that influences capital structure. Profitability shows the ability of a company to earn profits in relation to sales, total assets, and own capital (Sartono, 2008). In this study profitability ratios are measured by return on equity (ROE) and return on assets (ROA). Return on equity (ROE) is a ratio that shows the company's ability to generate net income for the return of shareholders' equity. The greater the ROE means the more efficient the company uses its own capital to generate investor profits planted in the company (Horne and John, 2012). Return on Assets is the rate of return on assets in determining the amount of net income generated from company assets by connecting net income to total assets (Keown and Martin, 2010). The increasing ratio shows that management's performance has increased in managing operational funding sources effectively to generate net income.

Profitability is a factor that is considered in determining the company's capital structure. According to Riyanto (2011) companies that have relatively stable profits will always be able to fulfill their financial obligations as a result of the use of foreign capital and can have better opportunities to make loans or withdrawal of foreign capital. The higher level of profitability (return on equity) will make it easier for companies to get foreign funds in the form of debt to finance their company's activities. The higher the debt, the greater the proportion of capital structure. Companies - companies with high levels of profitability will certainly try to reduce taxes by increasing the debt ratio, so that the additional debt will reduce taxes. According to Hanafi (2004) the trade-off theory indicates the existence of savings between taxes from debt and bankruptcy costs. The greater the proportion of debt, the greater the tax protection obtained. On the other hand, the greater the proportion of debt, the greater the bankruptcy costs that may arise. The optimal capital structure can be achieved by balancing the benefits of tax protection with the burden as a result of increasing use of debt (Sartono, 2008). So return on equity affects the debt to equity ratio.

\section{H2: Return On Equity has an effect on Debt to Equity Ratio}

According to Brigham and Houston (2011), companies with a high rate of return on investment using debt that is relatively small because of the high rate of return allows the company to finance most of the funding needs with funds generated internally. On the grounds that internal funds are cheaper than external funds, the company will use retained earnings before deciding to use debt. This is in accordance with the pecking order theory which states that companies prefer funding from the company's operations in the form of retained earnings. Internal funds are preferred because it allows companies to no longer need to open themselves from the spotlight of outside investors. So based on the pecking order theory, profitability will affect the level of debt of the company, where the higher the profitability (return on assets), the use of debt will be less so that the debt to equity ratio will decrease.

\section{H3: Return On Asset affects the debt to equity ratio}

Asset structure is related to the number of assets that can be used as collateral. Companies whose assets are sufficient to be used as collateral for loans, in other words, their assets have a comparison of fixed assets greater than current assets tend to use more debt because existing fixed assets can be used to determine how much debt can be taken and this will affect determination of the size of the capital 
structure (Brigham and Houston, 2011). The asset structure is measured by comparing between fixed assets and total assets owned by the company or Fixed Asset Ratio (FAR).

Brigham and Houston (2011) state that companies whose assets are suitable as collateral for loans tend to use debt more. According to Riyanto (2011) a company whose majority of its assets come from fixed assets, will prioritize meeting its funding needs with debt. Companies with a large number of fixed assets can use more debt, because fixed assets can be used as a good guarantee of company loans. Meanwhile, according to Lukas (2008) companies that have relatively large fixed assets will tend to use foreign capital in their capital structure. This is done because fixed assets such as land, and buildings can be used as collateral for debt. Based on the trade-off theory, companies will use debt to a certain point if the company has sufficient assets. The use of corporate debt will increase when the condition of a company's fixed assets increases. Companies that have large amounts of fixed assets will have more debt as a source of funding because these assets can be used as collateral. Thus it can be concluded that the higher the asset structure of the company shows the higher the ability of the company to be able to guarantee the debt borrowed. Conversely, the lower the asset structure of a company shows the lower the ability of the company to be able to guarantee its debt. In other words, the asset structure in the company has an influence in determining financing sources

H4: Fixed Asset Ratio affects the Debt to Equity Ratio

Mayangsari (2001) states that funding decisions are related to the selection of funding sources both from within and from outside. The source of corporate funds from the internal comes from retained earnings and depreciation. Funds obtained from external sources are funds originating from creditors and owners, participants or shareholders in the company. Meeting the needs of funds originating from credit is a debt to the company or referred to as the method of spending with debt. Funds obtained from the owners are their own capital. The proportion between the use of own capital and debt in meeting other needs of the company is called the company's capital structure.

Capital structure can be measured by the ratio of the ratio of total debt to own capital (Husnan and Pudjiastuti, 2012). Because the capital structure policy becomes important for the company, the company's financial managers need to identify the factors that influence the selection of capital structure.

\section{Methods}

The type of research used in this study is classified as causative research. Causative research is a type of research to analyze the influence of several variables on other variables (Nur and Bambang, 1999). This study aims to examine the relationship of independent variables to the dependent variable. This study attempts to explain the effect of sales growth, ROE, ROA, and Fixed Asset Ratio (FAR) as independent variables on the company's capital structure as a dependent variable on Real Estate and Property companies listed on the Indonesia Stock Exchange.

The research population is all Real Estate and Property Companies listed on the Indonesia Stock Exchange in the period 2013-2017, while sampling uses the purposive sampling method with criteria: (1) Real Estate and Property Companies listed on the IDX, (2) companies that have publish financial statements during the year of observation, and (3) companies that have net income for the year of observation, namely 2013-2017 so that 13 companies that meet these criteria are obtained.

The dependent variable (Y) in this study is the debt to equity ratio (DER). Debt to Equity Ratio (DER) is calculated as follows:

$$
\text { DER }=\frac{\text { Total of Debt }}{\text { Total of Equity }}
$$

While the independent variables in this study are sales growth (X1), Return On Equity (X2), return on assets (X3) and Fixed Asset ratio (X3). Sales Growth (SG) can be measured by the following formula: 


$$
\mathrm{SG}(\mathrm{X} 1)=\frac{S_{1}-S_{t-1}}{S_{t-1}}
$$

Information :

$\mathrm{SG}=$ Sales growth

$\mathrm{S}_{1}=$ Current Year Sales

$\mathrm{S}\left(\mathrm{St}_{\mathrm{t}-1)}=\right.$ Previous Year Sales

Return on equity (ROE) is measured by the following formula:

$$
\operatorname{ROE}(\mathrm{X} 2)=\text { Earning Aftex Tax / Total of Equity }
$$

Return on asset (ROA) is measured by the following formula:

$$
\operatorname{ROA}(\mathrm{X} 3)=\text { Earning Aftex Tax / Total of Asset }
$$

Fixed Asset Ratio (FAR) is calculated by the formula:

$$
\text { FAR }(X 4)=\text { Fixed Asset/ Total of Asset }
$$

This study uses multiple regression analysis techniques with the following equations:

$$
\mathrm{DER}=\mathrm{a}+\mathrm{b}_{1} \mathrm{SG}+\mathrm{b}_{2} \mathrm{ROE}+\mathrm{b}_{3} \mathrm{ROA}+\mathrm{b}_{4} \mathrm{FAR}+\mathrm{e}
$$

Information

$\mathrm{Y}$ : Debt to Equity Ratio

$\alpha$ : Constanta

$b_{1234}$ : Free Variable Regression Coefficient

FAR : Asset Structure
SG : Sales Growth

ROE : Return On Equity

ROA : Return On Assets

e : Residual Variables

\section{Results and Discussion}

\section{Normality Test}

The results of normality testing can be seen in Table 1 below

Table 1 Normality Test One-Sample Kolmogorov-Smirnov Test

\begin{tabular}{llr}
\hline \multirow{2}{*}{$\mathrm{N}$} & & Unstandardized Residual \\
\hline \multirow{2}{*}{ Normal Parameters ${ }^{\mathrm{N}}$} & \multicolumn{1}{c}{ Mean } & 65 \\
\cline { 2 - 3 } & Std. Deviation & .0000000 \\
\hline \multirow{2}{*}{ Most Extreme Differences } & Absolute & .31735870 \\
\cline { 2 - 3 } & Positive & .142 \\
\cline { 2 - 3 } & Negative & .142 \\
\hline Kolmogorov-Smirnov Z & & -.075 \\
\hline Asymp. Sig. (2-tailed) & & 1.146 \\
\hline
\end{tabular}

a. Test distribution is Normal.

Source: SPSS 16 Data Results

Based on Table 1, it can be seen that the test results state that the Kolmogrov-Smirnov value is 1,146 with a significance of 0.145 . With these results, it can be stated that the data used in the study is normally distributed, because the significance value of the normality test for each variable is greater than $0.05(0.145>0.05)$. 


\section{Multicollinearity Test}

The results of the multicollinearity test can be seen in Table 2 .

Table 2 Multicollinearity Test

\begin{tabular}{|c|c|c|c|c|c|c|c|}
\hline \multicolumn{8}{|c|}{ Coefficientsa } \\
\hline & \multirow{2}{*}{ Model } & \multicolumn{2}{|c|}{$\begin{array}{l}\text { Unstandardized } \\
\text { Coefficients }\end{array}$} & \multirow{2}{*}{$\begin{array}{c}\begin{array}{c}\text { Standardized } \\
\text { Coefficients }\end{array} \\
\text { Beta }\end{array}$} & \multirow[t]{2}{*}{ Sig. } & \multicolumn{2}{|c|}{$\begin{array}{l}\text { Collinearity } \\
\text { Statistics }\end{array}$} \\
\hline & & B & Std. Error & & & Tolerance & VIF \\
\hline 1 & (Constant) & .852 & .079 & & .000 & & \\
\hline & SG & -.057 & .161 & -.043 & .722 & .816 & 1.226 \\
\hline & ROE & 1.652 & .460 & .510 & .001 & .579 & 1.728 \\
\hline & ROA & -3.283 & 1.296 & -.386 & .014 & .500 & 2.001 \\
\hline & FAR & 2.406 & .703 & .374 & .001 & .978 & 1.022 \\
\hline
\end{tabular}

a. Dependent Variable: DER

\section{Source: SPSS 16 Statistical Results}

Table 2 shows that all variables have a Tolerance value of more than 0.10 and Variance Inflation factor (VIF) is less than 10, so it can be concluded that there is no multicolonity between all the independent variables found in the research.

\section{Heteroscedacity test}

The results of the observation with the Scatterplot graph method obtained the following results:

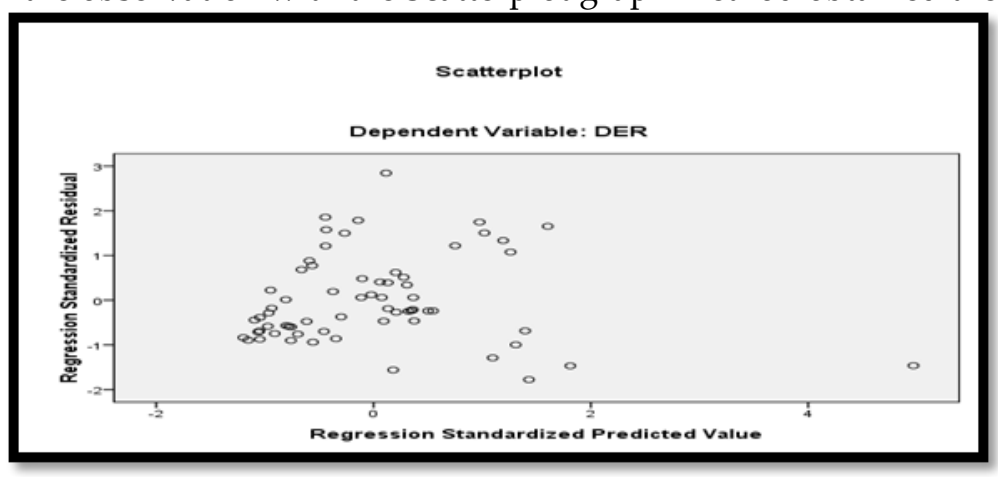

Figure 2 Scatterplot

Based on Figure 2, it can be seen that the Scatterplot points spread randomly and did not form a specific pattern so that it can be concluded that heterocedasticity did not occur in the regression model.

\section{Autocorrelation Test}

The autocorrelation test results can be seen in Table 3 .

Table 3 Autocorrelation Test Results

\begin{tabular}{cccccc}
\hline Model & $\mathbf{R}$ & $\begin{array}{c}\mathbf{R} \\
\text { Square }\end{array}$ & $\begin{array}{c}\text { Adjusted } \\
\text { R Square }\end{array}$ & $\begin{array}{c}\text { Std. Error of } \\
\text { the Estimate }\end{array}$ & Durbin-Watson \\
\hline 1 & $.549^{\mathrm{a}}$ & .301 & .255 & .32777 & 1.031 \\
\hline
\end{tabular}

a. Predictors: (Constant), FAR, SG, ROE, ROA

b. Dependent Variable: DER

Source: SPSS 16 Data Results

Based on Table 3, it is known that the Durbin-Watson value is 1.031 . Where the value is between $-2<1.031<+2$. These results indicate that the regression model does not have autocorrelation. 


\section{Test of Multiple Regression Analysis}

Multiple Regression Test can be seen in Table 4 below:

Table 4 Multiple Regression Test Results Coefficientsa

\begin{tabular}{|c|c|c|c|c|c|c|}
\hline & \multirow[t]{2}{*}{ Model } & \multicolumn{2}{|c|}{$\begin{array}{l}\text { Unstandardized } \\
\text { Coefficients }\end{array}$} & \multirow{2}{*}{$\begin{array}{c}\text { Standardized } \\
\text { Coefficients }\end{array}$} & \multirow[t]{2}{*}{$\mathbf{t}$} & \multirow[t]{2}{*}{ Sig } \\
\hline & & B & Std. Error & & & \\
\hline \multirow{5}{*}{1} & (Constant) & .852 & .079 & & 10.747 & .000 \\
\hline & SG & -.057 & .161 & -.043 & -.358 & .722 \\
\hline & ROE & 1.652 & .460 & .510 & 3.594 & .001 \\
\hline & ROA & -3.283 & 1.296 & -.386 & -2.532 & .014 \\
\hline & FAR & 2.406 & .703 & .374 & 3.424 & .001 \\
\hline
\end{tabular}

a. Dependent Variable: DER

Source: SPSS 16 Data Results

Based on the results in Table 4, the following equations can be formulated:

$$
\text { DER }=0,852-0,057 \text { SG + 1,652 ROE - 3,283 ROA + 2406 FAR }
$$

\section{Determination Coefficient Test $\left(\mathbf{R}^{2}\right)$}

Based on Table 3, it can be seen that the Adjusted R2 value obtained is equal to 0.255 . This shows that the capital structure (Debt to Equity Ratio) of real estate and property companies listed on the Stock Exchange can be explained by the independent variables namely sales growth (SG), Return on Assets (ROA), Return On Equity (ROE) and asset structure of $25.5 \%$, while the remaining $74.5 \%$ is determined by other variables not analyzed in this study.

\section{F Statistics Test}

F Test Results can be seen in table 5 below

Table 5 Test $\mathbf{F}$

\begin{tabular}{llccccc}
\hline Model & Sum of Squares & df & Mean Square & F & Sig. \\
\hline \multirow{2}{*}{1} & Regression & 2.781 & 4 & .695 & 6.471 & $.000^{\mathrm{a}}$ \\
\cline { 2 - 7 } & Residual & 6.446 & 60 & .107 & & \\
\cline { 2 - 7 } & Total & 9.227 & 64 & & & \\
\end{tabular}

a. Predictors: (Constant),FAR, SG, ROE, ROA

b. Dependent Variable: DER

Source: SPSS 16 Data Results

Based on Table 5, it can be seen that the calculated F value is 6.471 with F Table of 2.53 then (6.471> 2.53) with a significance level of $0.000<0.05$. This means that there is a significant effect together between all independent variables on the dependent variable.

\section{Hypothesis Test ( $t$ test)}

The first hypothesis is sales growth (SG) influences the capital structure (DER). Based on Table 4 it is known that the coefficient of Sales Growth is negative 0.057 and the value of $t$ count is negative 0.358 with a significance of $0.722>0.05$. This means that sales growth has a negative and not significant effect on the capital structure of real estate and property companies listed on the Stock Exchange in 2013 - 2017, so it can be said that the first hypothesis was rejected.

The second hypothesis is the Return On Equity effect on the capital structure. Based on Table 4 it is known that the profitability coefficient value is positive 1.652 and the value of $t$ count is 3.594 with a significance of $0.001<0.05$. This means that ROE has a positive and significant effect on the structure 
of real estate and property capital listed on the IDX in 2013 - 2017. So it can be said that the second hypothesis is accepted.

The third hypothesis is Return On Asset has an effect on capital structure. Based on Table 4 it is known that the profitability coefficient value is negative -3.283 and the value of $t$ count is negative 2.532 with a significance of $0.014<0.05$. This means that ROA has a negative and significant effect on the structure of real estate and property capital listed on the IDX in 2013 - 2017. So it can be said that the third hypothesis is accepted.

The fourth hypothesis in this study is the asset structure influences the capital structure. Based on Table 4 it is known that the asset structure coefficient value is positive 2.406 and the value of $t$ count is 3.424 with a significance of $0.001<0.05$. This means that the asset structure has a positive and significant effect on the structure of the real estate and property capital listed on the IDX in 2013 2017. So it can be said that the fourth hypothesis is accepted

\section{Effect of Sales Growth on Debt to Equity Ratio}

The sales growth variable has a negative and not significant effect on the Debt to Equity Ratio as evidenced by the test results of the Sales Growth negative value of 0.057 and the calculated $t$ value is negative 0.358 with a significance of $0.722>0.05$. This significance value indicates the change in the value of sales growth does not affect the change in the company's Debt to Equity Ratio.

The results of this study support the Pecking Order Theory, where the higher sales growth will use more internal funds in the form of retained earnings. This is certainly in accordance with the basic Pecking Order Theory concept which states that companies prefer internal funding compared to external funding. This condition shows the ups and downs of sales growth does not affect debt because the company does not use external funding but uses profits from within the company, namely profits obtained from sales that are used for company operations so that the company does not use debt. This is due to the high level of sales that does not tend to make the company take debt and enlarge its capital structure.

The results of this study are consistent with the research conducted by Kesuma (2009) and the research of Puspawardani (2013) which states that sales growth has a negative and not significant effect on capital structure. But the results of this study do not support the research conducted by Novione and Rusmala (2016) and the research of Farisa and Widati (2017) which states that sales growth has a positive and significant influence on the company's capital structure.

\section{Effect of Return On Equity on Debt to Equity Ratio}

The Retrun On Equity variable has a positive and significant effect on the Debt to Equity Ratio as evidenced by the positive ROE test results of 1.652 and the calculated $t$ value is positive 3.594 with a significance of $0.001<0.05$. This significance value indicates changes in the value of profitability will affect changes in the company's capital structure.

The higher level of profitability will make it easier for companies to get foreign funds in the form of debt to finance their company's activities. The higher the debt, the greater the proportion of capital structure. Companies - companies with high levels of profitability will certainly try to reduce taxes by increasing the debt ratio, so that the additional debt will reduce taxes. According to Hanafi (2004) the trade-off theory indicates that there is a savings in taxes from debt and bankruptcy costs. The greater the proportion of debt, the greater the tax protection obtained. On the other hand, the greater the proportion of debt, the greater the bankruptcy costs that may arise. Thus, an optimal capital structure can be achieved by balancing the benefits of tax protection with the burden as a result of increasing use of debt (Sartono, 2008).

The results of this study are in line with the research of Hadiyanto (2008), Dewa and Gede (2017) research and Andre and Karya's (2014) research which states that profitability has a positive and significant effect on capital structure. But it is contrary to Zulfia's (2016) research and Farisa and Widati (2017) research which states that profitability has a negative effect on capital structure. 


\section{Effect of Return on Asset on Debt to Equity Ratio}

The variable Return On Assets (ROA) has a positive and significant effect on the capital structure as evidenced by the ROA regression test results which are negative 3.283 and the value of $t$ count is negative 2.532 with a significance of $0.014<0.05$. This shows that if the ROA increases, the debt to equity ratio will experience a decline in which the capital structure decreases as a result of reduced debt that can be repaid with rising profits.

The results of this study are in accordance with the pecking order theory, namely companies prefer funding from the results of company operations in the form of retained earnings. Internal funds are preferred because it allows companies to no longer need to open themselves from the spotlight of outside investors. So based on the pecking order theory, profitability will affect the level of debt of the company, where the higher the profitability, the use of debt will be less so that the capital structure will decrease. So that profitability has a negative effect on capital structure.

The results of this study are in accordance with the theory put forward by Brigham and Houston (2011), companies with high returns on investment using relatively small debt. High rates of return allow companies to finance most of the funding needs with funds generated internally. The results of this study are also in line with the research conducted by Lina and Amir (2018) and Zulfia (2016) research based on his research stating that Return On Assets (ROA) has a negative and significant effect on capital structure. But unlike the results of Andre and Karya's (2014) research, profitability has a positive and significant effect on capital structure.

\section{Effect of Fixed Asset Ratio on Debt to Equity Ratio}

Fixed asset ratio (FAR) variables have a positive and significant effect on the debt to equity ratio as evidenced by the test results which are positive at 2.406 and the value of $t$ count is positive 3.424 with a significance of $0.001<0.05$. This significance value indicates changes in the value of asset structure affect changes in the company's capital structure.

The results of this study are in accordance with the theory put forward by Brigham and Houston (2011) which states that companies whose assets are suitable as collateral for loans tend to use debt more. This is because the fixed assets can be used as collateral if the company experiences financial difficulties so that the company will seek external loans. This is in accordance with a trade-off theory where the company will use debt as a source of funding for the company when the company has a good asset structure or has sufficient assets. The use of corporate debt will increase when the condition of a company's fixed assets increases. Companies that have large amounts of fixed assets will prefer debt as a source of funding because these assets can be used as collateral.

The results of this study are in accordance with the theory of forwarding by Brigham and Houston (2011) which states that companies are suitable for loans for loans to use debt more. The company experiences financial difficulties so that it will seek external loans. This is in accordance with a tradeoff theory where the company will use debt as a source of funding for the company when the company has a good asset structure or has sufficient assets. The use of corporate debt will increase when the condition of a company's fixed assets increases. Companies that have large amounts of assets will be used as collateral.

\section{Conclusions}

The conclusions of this study are (1) sales growth has a negative and not significant effect on the debt to equity ratio, (2) Return On Equity (ROE) has a positive and significant effect on the debt to equity ratio, (3) Return on Assets (ROA) has a negative effect and significant to the debt to equity ratio and (4) the fixed asset ratio (FAR) has a positive and significant effect on the debt to equity ratio.

The researcher expects the next researcher to develop research related to other factors that affect the company's capital structure, such as changing the object of research with other business sectors, adding to the observation period, and adding other variables such as taxes, liquidity, ownership structure, dividend policy and others and use different proxy and data processing methods to produce more accurate data processing and can see the impact on the company. 


\section{References}

Andre dan Karya. (2014). Pengaruh Profitabilitas, Struktur Aset dan Pertumbuhan Penjualan Terhadap Struktur Modal Serta Harga Saham. E-Jurnal Akuntansi Universitas Udayana 6.3 (2014): 514-530.

Bhawa dan Dewi. (2015). Pengaruh Ukuran Perusahaan, Likuiditas, Profitabilitas dan Risiko Bisnis Terhadap Strutkur Modal Perusahaan Farmasi. E-Jurnal Manajemen Unud, Vol. 4, No. 7, 2015 : 1949-1966. ISSN : 2302-8912.

Brigham EF,Houston JF. (2011). Dasar-Dasar Manajemen Keuangan Buku 2 Edisi 11. Jakarta: Salemba Empat

Dewa, Ayu Intan Yoga Mahadewi dan Gede Mertha Sudiartha. (2017). Pengaruh Profitabilitas, Ukuran Perusahaan, dan PertumbuhanAset Terhadap Struktur Modal dan Nilai Perusahaan. E-Jurnal Manajemen Unud, 6 (4), 2222-22252.

Fahmi, Irham. (2016). Pengantar Manajemen Keuangan. Bandung : Penerbit Alfabeta.

Farisa, Nurul Anggun dan Widati, Listyorini Wahyu. (2017). Analisa Profitabilitas, Likuiditas, Pertumbuhan Penjualan, Struktur Aktiva Dan Kebijakan Dividen Terhadap Struktur Modal. Prosiding Seminar Nasional Multi Disiplin Ilmu. 3(3), pp. 640-649.

Ghozali, Imam. (2007). Aplikasi analisis multivariate dengan program SPSS. Badan penerbit UNDIP. Semarang.

Hadianto, Bram. (2008). Pengaruh Struktur Aktiva, Ukuran Perusahaan, dan Profitabilitas terhadap Struktur Modal Emiten Sektor Telekomunikasi Indonesia Periode 2000-2006: Sebuah Pengujian Hipotesis Pecking Order, Jurnal Manajemen. 7 (2).

Halim, Abdul. (2015). Manajemen Keuangan Bisnis Konsep dan Aplikasinya. Jakarta : Penerbit Mitra Wacana Media

Hanafi, (2004). Manajemen Keuangan. Yogyakarta: BPFE UGM

Horne, J.C dan Jone.M. Machowicz. (2012). Prinsip-prinsip manajemen keuangan. Edisi 12. Salemba empat. Jakarta.

Husnan dan Pudjiastuti. (2012). Dasar-Dasar Manajemen Meuangan $6^{\text {th }}$. Yogyakarta: UPP STIM YKPN.

Keown, A. J dan J. D Martin. (2010). Manajemen keuangan: prinsip dan penerapan. Salemba empat. Jakarta.

Kesuma, Ali. (2009). Analisis Faktor yang Mempengaruhi Struktur Modal serta Pengaruhnya Terhadap Harga Saham Perusahaan Real Estate yang Go-Public Di BEI. Jurnal Manajemen \& Kewirausahaan. II. (1) 38-45.

Khariry dan Yusniar. (2016). Faktor-Faktor Yang Mempengaruhi Struktur Modal. Jurnal Wawasan Manajemen. 4 (2).

Lina1, Afriza dan Amir. (2018). Pengaruh Return On Asset, Current Ratio, Size Dan Growth Terhadap Struktur Modal Pada Perusahaan Manufaktur Yang Terdaftar Di Bursa Efek Indonesia Periode. Jurnal Riset Akuntansi Going Concern 13(4), 2018, 893-902.

Lukas, Atmaja Setia. (2008). Teori dan Praktek Manajemen Keuangan. Yogyakarta: Andi.

Lukman Syamsudin. (2007). Manajemen Keuangan Perusahaan. Jakarta : Raja grafindo persada.

Martono, Agus Harjitno. (2010). Manajemen Keuangan (Edisi 3). Yogyakarta: Ekonisia.

Mayangsari, Sekar. (2001). Analisis Faktor-Faktor yang Mempengaruhi Keputusahan Pendanaan Perusahaan: Pengujian Pecking Order Hipotesis. Media Riset Akuntansi, Auditing dan Informasi, 1(3), pp. 1-26

Normawaty dan Sonang. 2017. Pertumbuhan Perusahaan, Struktur aktiva, dan Pertumbuhan Penjualan Serta Pengaruhnya Terhadap struktur Modal. Jurnal ilmu dan Riset Manajemen Volume 6 Nomor 4.

Novione dan Rusmala Dewi. (2016). Pengaruh Pertumbuhan penjualan, Struktur Aktiva, dan Pertumbuhan Aktiva Terhadap Struktur Modal. E-jurnal manajemen unud. Vol 5. No 8.

Nur, Indriantoro dan Bambang Supomo, (1999). Metodologi Penelitian Bisnis untuk Akuntansi dan Manajemen. Edisi 1. Cetakan Pertama BPFE. Yogyakarta. 
Puspawardhani, Nadia. (2014). Pengaruh Pertumbuhan Penjualan, Profitabilitas, Struktur Aktiva dan Ukuran Perusahaan terhadap Struktur Modal pada Perusahaan Pariwisata dan Perhotelan $d i$ BEI. Jurnal Universitas Udayana.

Putri, Meidera Elsa Dwi. (2012). Pengaruh Profitabilitas, Struktur Aktiva dan Ukuran Perusahaan Terhadap Struktur Modal Pada Perusahaan Manufaktur Sektor Industri Makanan dan Minuman Yang Terdaftar Di Bursa Efek Indonesia (BEI). Jurnal Manajemen. Vol.01.1-10.

Riyanto, Bambang. (2011). Dasar-dasar Pembelanjaan Perusahaan. Edisi keempat Yogyakarta: BPFE. Sartono, Agus. (2008). Manajemen Keuangan Teori dan Aplikasi. Yogyakarta: BPFE.

Sartono, R. Agus dan Ragil Sriharto. (1999). Faktor-faktor Penentu Struktur Modal Perusahaan Manufaktur di Indonesia. Sinergi. (2) 175-188

Saswanto dan Lailatul. (2017). Pengaruh Profitabilitas, Struktur Aset dan Ukuran Perusahaan Terhadap Struktur Modal. Jurnal Ilmu dan Riset Akuntansi, Vol (6) 1.

Sofiati. 2001. Pengaruh Timbal Balik antara Utang dan Ekuitas Terhadap Struktur Modal Perusahaanperusahaan Go-Publik di Bursa Efek Jakarta.Kompak. Yogyakarta: STIE Yo. (Januari) : 40-56.

Subramanyam, K.R. dan John J. Wild. (2010). Analisis laporan keuangan. Jakarta: salemba empat.

Weston, J,F dan Brigham, E,F. (2005). Dasar-Dasar Manajemen Keuangan, Edisi Kesembilan, Jilid 2, Penerbit Erlangga, Jakarta.

Wing W. Winarno. (2009). Analisis ekonometrika dan statistika dengan eviews. Yogyakarta: Erlangga.

Yeni dan Mertha. (2015). Pengaruh Faktor Fundamental Terhadap Nilai Perusahaan di Bursa Efek Indonesia

Yuliana dan Vivi. (2015). Pengaruh Risiko Bisnis, Ukuran Perusahaan dan Pertumbuhan Penjualan Terhadap Struktur Modal. E-Jurnal Manajemen Unud, Vol. 4 No. 5.

Zulvia, Yolandafitri. (2016). Determinan Struktur Modal. Jurnal Kajian Manajemen Bisnis. Vol. 5, No. 1, Maret 2016. 